\title{
Neonatal-perforated appendix forming antibioma masquerading as duodenal duplication
}

\author{
Ramnik V Patel, ${ }^{1,2}$ Lisa Marie Brown, ${ }^{3}$ Bharat More, $^{3}$ Richard Stewart $^{3}$
}

${ }^{1}$ Department of Paediatric Urology, University College London Hospitals NHS Foundation Trust, London, UK ${ }^{2}$ Department of Paediatric Urology, Great Ormond Street Children Hospital NHS Trust, London, UK

${ }^{3}$ Department of Paediatric Surgery, QMC, Nottingham, UK

\section{Correspondence to} Ramnik V Patel, ramnik@doctors.org.uk
To cite: Patel RV, Brown LM, More B, et al. BMJ Case Rep Published online: [please include Day Month Year] doi:10.1136/ bcr-2013-200067

\section{DESCRIPTION}

A 17-day-old previously healthy breastfed neonate with normal antenatal scans born at full term by an emergency caesarean section for failure to progress and passed meconium in the first $2 \mathrm{~h}$ of life, became irritable with vomiting, refusal of feeds and fever. On examination, he was febrile (38.5), tachycardic with a tender abdomen. He underwent a partial septic screen at the district general hospital which showed normal urine, cerebrospinal fluid (CSF) and chest X-ray and the white blood cell count was $26 \times 10^{9} / \mathrm{L}$, neutrophils $16.4 \times 10^{9} / \mathrm{L}$ and $\mathrm{C}$ reactive protein (CRP) $283 \mathrm{mg} / \mathrm{L}$. He was resuscitated and started on cefotaxime and metronidazole. An abdominal ultrasound showed a cystic lesion between the liver and the duodenum and the patient was transferred to us on the third day. He settled, became afebrile but had an abdominal mass and the CRP was $136 \mathrm{mg} / \mathrm{L}$. An abdominal CT scan confirmed a cystic lesion with enhancing walls, air fluid levels and in proximity of duodenum indicating a duplication cyst (figure 1). Examination under anaesthesia showed a palpable mass in the right upper quadrant and laparoscopy converted to a laparotomy revealed an appendicular antibioma with walled-off perforated appendicitis with pseudocyst formation in the subhepatic position, which was drained and an appendicectomy performed. Postoperative recovery was uneventful. Histology confirmed acute appendicitis with antibioma/pseudocyst formation. He is well and thriving at a 6-year follow-up. Neonatal appendicitis in a term infant with mass, pseudocyst or antibioma formation is very rare and only reported once. ${ }^{1}$ The ultrasound findings were secondary to formation of postnatal pseudocyst following administration of higher antibiotics soon after the appendix was perforated. Neonatal appendicitis is seen in male, preterm, necrotising enterocolitis, Hirschsprung's disease, cystic fibrosis, meconium plug syndrome. ${ }^{2}{ }^{3}$ One way to immediately rule them out was to investigate for each of them or to follow them clinically if he develops any symptoms. This fact was discussed with the parents and they wanted to observe and investigate only if symptomatic. Whenever possible, a diagnostic laparoscopy with a view to therapeutic intervention should be performed.
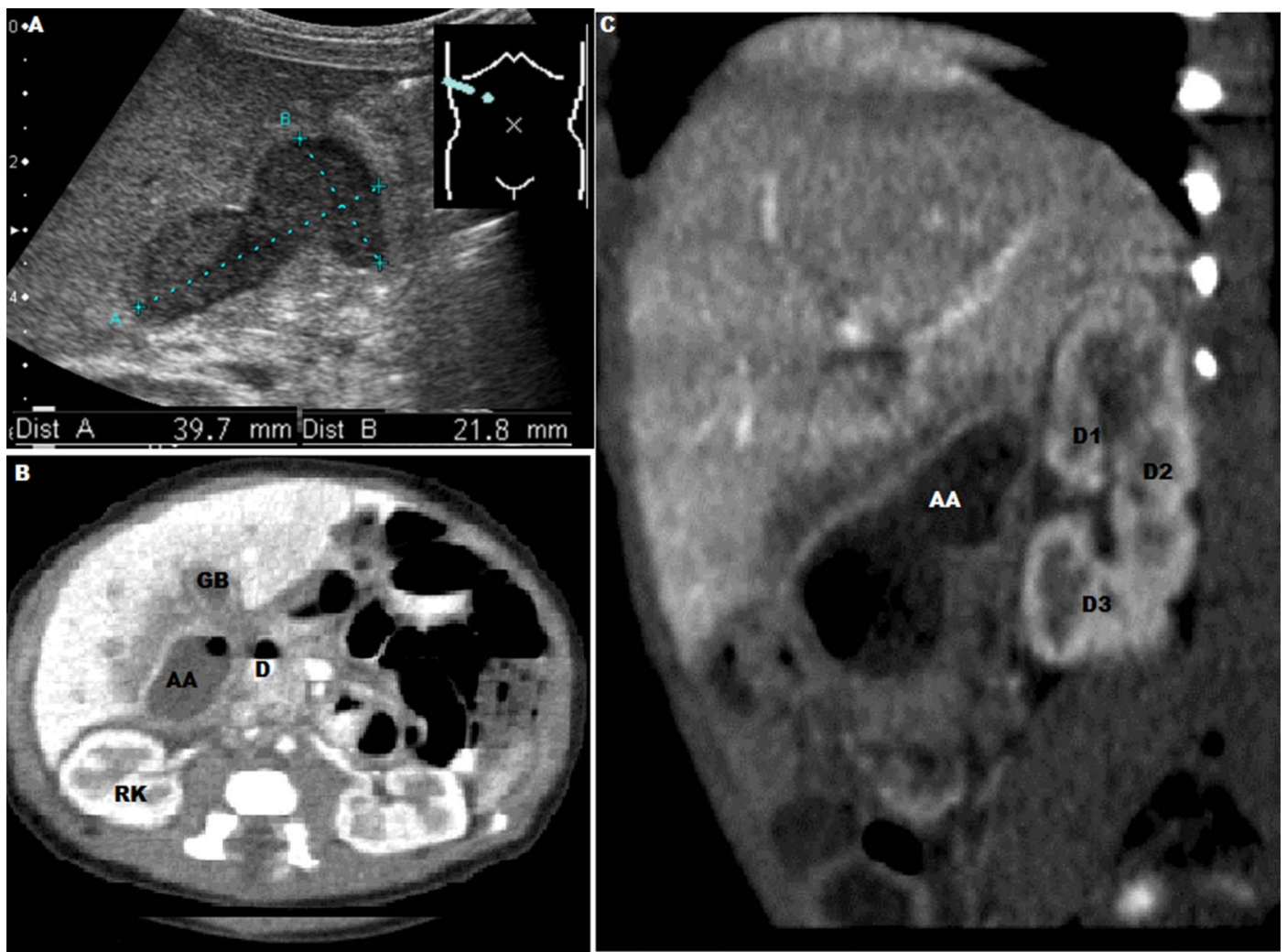

Figure 1 (A-C) An abdominal ultrasound scan showing dumbbell-shaped thick-walled cystic lesion.

Contrast-enhanced CT scan showing contrast-enhancing cyst walls with air fluid in the cavity and no bowel contrast in the subhepatic cystic lesion. AA, appendicular antibioma; D, duodenum; GB, gall bladder; RK, right kidney. 


\section{Learning points}

- Neonatal appendicitis forming an antibioma or a pseudocyst postnatally is a rare complication in a term neonate.

- Coexisting diseases and predisposing factors need to be ruled out clinically or by investigations.

- Prompt recognition of sepsis and broad spectrum antibiotics may wall off appendicitis even in term-healthy neonates forming a thick-walled cyst containing sterile fluid which constitutes an antibioma with high CRP, but a clinically healthy baby with an abdominal mass.
Contributors All authors have actively contributed to the clinical and operative management of this case and active participation in preparation, data gathering, writing, analysing and critically appraising this manuscript.

Competing interests None.

Patient consent Obtained.

Provenance and peer review Not commissioned; externally peer reviewed.

\section{REFERENCES}

1 Saeki I, Yamanouchi T, Tanaka S, et al. Neonatal appendicitis mimicking intestinal duplication: a case report. J Med Case Rep 2012;6:286

2 Kayastha K. Neonatal perforated appendicitis. J Neonat Surg 2012;1:10.

3 Khan RA, Menon P, Rao KLN. Beware of neonatal appendicitis. J Indian Assoc Pediatr Surg 2010;15:67-9.

Copyright 2013 BMJ Publishing Group. All rights reserved. For permission to reuse any of this content visit http://group.bmj.com/group/rights-licensing/permissions.

BMJ Case Report Fellows may re-use this article for personal use and teaching without any further permission.

Become a Fellow of BMJ Case Reports today and you can:

- Submit as many cases as you like

- Enjoy fast sympathetic peer review and rapid publication of accepted articles

- Access all the published articles

- Re-use any of the published material for personal use and teaching without further permission

For information on Institutional Fellowships contact consortiasales@bmjgroup.com

Visit casereports.bmj.com for more articles like this and to become a Fellow 